\title{
British Signals Intelligence and the 1916 Easter Rising in Ireland
}

ABSTRACT Historians for decades have placed Room 40, the First World War British naval signals intelligence organization, at the centre of narratives about the British anticipation of and response to the Easter Rising in Ireland in 1916. A series of crucial decrypts of telegrams between the German embassy in Washington and Berlin, it has been believed, provided significant advance intelligence about the Rising before it took place. This article upends previous accounts by demonstrating that Room 40 possessed far less advance knowledge about the Rising than has been believed, with most of the supposedly key decrypts not being generated until months after the Rising had taken place.

\section{INTRODUCTION}

A key moment in twentieth century Irish history, on Easter Monday 1916 a group of rebels launched in Dublin an uprising against British rule. Carefully prepared in advance, the Irish rebels had previously sought German assistance in providing arms and in organizing transport for famed Irish nationalist Roger Casement. The Germans agreed to provide this assistance, dispatching Casement aboard a German submarine and organizing a covert landing of munitions aboard a merchant ship masquerading as the Norwegian steamer Aud. The arms, however, were intercepted and Casement captured by the British authorities. Notwithstanding these reverses, the uprising went forward shortly thereafter on Easter Monday, 24 April 1916. Though apparently catching the British authorities in Ireland by surprise, the uprising was put down by the British in a violent crackdown.

For decades, signals intelligence has been treated as the linchpin in our understanding of the British anticipation of and response to these events. British signals intelligence organization Room 40, we are told, intercepted and decrypted a number of key telegrams between the German ambassador in Washington and Berlin. These decrypts, as was summarized very recently, 'gave full warning of the Easter Rising' and 'revealed Germany's plans'. 'This has been repeated so frequently, and by such august historians as Christopher Andrew, Keith Jeffery, and Richard Aldrich, that it is treated as an undisputed and well-established fact in the intelligence literature. ${ }^{2}$ In the only especially detailed examination of British intelligence and the Easter Rising, Geoff Sloan's article published in this journal in 2013, this assumption formed the cornerstone of his analysis. These decrypts, Sloan argued, provided the British with 'a comprehensive understanding and knowledge of the planned rebellion' long before it took place. ${ }^{3}$

Believing that British intelligence possessed detailed advance knowledge of the events before they transpired, scholars have pinned blame variously on British intelligence officials, the British administration in Ireland at Dublin Castle, and the British cabinet in London for failures to share or act upon vital information. Unable to explain how such seemingly clear and unambiguous intelligence failed to spur the British government into action to head off the Rising, earlier scholars accused the head of Room 40, Reginald Hall, of hiding the intelligence from policymakers for political reasons. By contrast,

\footnotetext{
${ }^{1}$ Aldrich and Cormac, Black Door, 30-31.

2 Andrew, Secret Service, 246-247; Andrew, "Casement and British Intelligence”, 79; Andrew, Defence of the Realm, 87; Jeffery, 1916, 100-103; Aldrich and Cormac, Black Door, 30-31.

3 Sloan, "British State", 472.
} 
Sloan attempts to rebut the charges against Hall and instead assigns blame to Asquith's government and to Dublin Castle for not reacting to the intelligence in a 'failure of response'.4

This article aims to upend previous accounts on this subject by demonstrating that almost all of the decrypts that scholars have long believed played a key role in these events were, in reality, decrypted months after the Rising took place, and could therefore have played no role whatever in the British response. Room 40 did not generate a treasure trove of intelligence in the lead-up to the Easter Rising. Rather, only one very short relevant decrypt appears to have been in Room 40's possession prior to April 1916, a decrypt that later appears to have been supplemented with a couple of small snippets of information from British naval wireless decryption efforts. Hall had no advance proof, as has long been supposed, of a joint conspiracy between the German government and the Irish rebels. While the one brief decrypt that existed was vital to the British government's unravelling of the German-Irish conspiracy prior to the Rising, and Sloan is correct that Hall did not suppress this decrypt, the decrypt provided only very limited information.

The key to understanding the problem of precisely when these important telegrams were decrypted lies in examining the methods of German communication between Berlin and its embassy in Washington. At this time there were three, of which the principal one was what has become known as the 'Swedish Roundabout'. German diplomatic telegrams were disguised and communicated by the Swedish government, using a circuitous route. Most of the telegrams relevant to the Easter Rising appear to have been sent using this method. This article aims to reliably date Room 40's detection of the Swedish Roundabout to summer 1916, well after the Easter Rising took place. The one telegram that appears to have been decrypted prior to the Rising was sent via an alternative route, the U.S. State Department, that the British are known to have been monitoring from at least late 1915 onwards.

This article will explore the documentary and historiographical reasons why this mistaken belief that Room 40 possessed a significant cache of decrypts has arisen. It will examine the telegrams previously believed to have been in British possession. To demonstrate why only one of these decrypts can reasonably be shown to have been produced before the Rising took place, the article will analyse the methods of German diplomatic communication and British intelligence efforts to detect them. To provide an important independent check, the article will consider a few textual indications that also support the argument of this article that only one diplomatic decrypt was in British possession prior to the Rising. Finally, the article will consider some of the implications of this finding.

For reasons of space and scope, this article necessarily limits itself to an examination of British signals intelligence in relation to the Rising. Though the British government had some modest human intelligence available to it, the questions of human intelligence sources, and of how we are now to evaluate the government's response to the Rising in the light of this article's findings, are left for future research. Adequately examining why this misunderstanding has arisen and correcting it requires detailed explanation, and attempting then to reconsider British human intelligence and the British response to the Rising more generally would require an article of unwieldy length and breadth. In light of this article's conclusions, however, a renewed examination of the intelligence in British possession prior to the Rising, and of the British authorities' use of that intelligence, is clearly indicated. This article aims to provide sound foundations for such a study.

\section{ORIGINS AND HISTORIOGRAPHY}

\footnotetext{
${ }^{4}$ Sloan, "British State".
} 
Considering the frequency of the repetition of the notion that Room 40 played a key role in the British response to the Easter Rising, it is surprising how little the subject has been subjected to any serious or detailed analysis. Although there are numerous accounts attempting to summarize the events in a couple of paragraphs, only a few authors devote as much as a page or two to these events, and only one attempt at an exhaustive account of British intelligence and the Easter Rising exists, that of Geoff Sloan's article published in this journal in 2013.

The ubiquitous belief that Room 40 had detailed prior knowledge of the Rising can be traced back to one principal source, which historians have universally cited either directly or indirectly: a volume entitled Documents Relative to the Sinn Fein Movement, published by the British government in early January $1921 .{ }^{5}$ Released to the public in the latter stages of the Irish War of Independence, this volume was part of an 'official effort to effort to paint Sinn Fein and Irish Republicanism as hostile to British and democratic interests'. It sought to demonstrate to the public the extent of the wartime connection between the Irish rebel factions and the Imperial German Government. ${ }^{6}$

For historians, notwithstanding its propaganda intent, this volume is highly useful and contains vast amounts of important original documentation. Concerning the Easter Rising, the volume contains a significant number of decrypts in British possession in 1921 that show much of the extent of the German-Irish collaboration in the conspiracy. While the volume includes the dates the original telegrams were dispatched, it does not however contain the dates that the telegrams were decrypted. Previous historians leapt to an understandable but unfounded assumption: that there were no significant delays between the sending of these telegrams and their decryption.

The earliest suggestion of this appears to have come in William James's flattering popular biography of Reginald Hall, The Eyes of the Navy, published in 1955. James writes:

[E]arly in 1916 messages about landing munitions in Ireland left no doubt...that the attempt would soon be made... Hall was able to follow every move of the plotters, and during the week before Easter Sunday was watching eagerly for the message with the password that would mean that Casement and the arms had sailed.

Yet though it appears that James was referring here to the 1921 Documents Relative to the Sinn Fein Movement volume, he provides neither evidence nor elaboration. ${ }^{7}$

Leon Ó Broin's more considered Dublin Castle and the 1916 Rising, published in 1966, approached the matter cautiously, combining the 1921 documentary volume with James's book and other limited knowledge then available about Room 40. Pointing out some discrepancies in the evidence, Ó Broin acknowledged that these incongruities 'may mean that the interception was not as complete as it was claimed to be', but he thought it more likely that Hall 'would have preferred that the rebellion in Ireland should succeed rather than that Britain should lose' a key source of intelligence. ${ }^{8}$ Popular intelligence historian Patrick Beesly was similarly cautious in 1982, writing that 'Room 40 intercepted at least thirtytwo messages dealing with German assistance for Sinn Fein... but it is not now clear how many of them were made or decoded before the Easter Rising, or that all of them were decoded contemporaneously?.

Eunan O’Halpin in 1984 abandoned Ó Broin's and Beesly's caution. Citing James and Ó Broin and mentioning the 1921 volume among a handful of other documentation, O'Halpin wrote that Hall 'had an

\footnotetext{
${ }^{5}$ Documents Relative to the Sinn Fein Movement, "Sinn Fein and Germany", 10 January 1921, Times, 1.

${ }^{6}$ Costello, "Role of Propaganda", 10.

${ }^{7}$ James, Eyes of the Navy, 110-111.

8 Ó Broin, Dublin Castle, 137-140.

${ }^{9}$ Beesly, Room 40, 187.
} 
outstanding and unimpeachable source of information on German plans for Ireland, as his staff had broken the telegraphic code in which messages were passed between the German Foreign Office and its embassy in Washington'. Unable to see how the British authorities in Ireland and the Cabinet could have failed to act if they had received these decrypts, O'Halpin originated the argument that Hall had suppressed the intelligence. It was 'clear', he wrote, 'that Hall was anxious above all to avoid disclosing his source, decrypted German messages; in so doing he jeopardised the security of Ireland'. Going further, O'Halpin raised the accusatory 'possib[ility] that [Hall] intended the rebellion to take place, knowing that it would be crushed and that the government would be obliged to follow a policy of repression in its wake', and he criticized Hall for having 'deliberately misled the Irish authorities'.10

Christopher Andrew in his book Secret Service the following year formulated the standard account that has been widely repeated since. Citing O'Halpin, Andrew credited the decrypts for Britain's foiling of the German-Irish conspiracy, but blamed Hall for failing to share the intelligence with the civilian authorities and therefore allowing the Rising to go forward. ${ }^{11}$ With Andrew again putting forward this version of events in his 2005 book chapter 'Casement and British Intelligence'12 and in his 2009 Defence of the Realm, ${ }^{13}$ this interpretation has been repeated several times, most recently by Keith Jeffery in $2015^{14}$ and by Richard Aldrich and Rory Cormac in 2016, ${ }^{15}$ and by an array of intelligence authors in between. ${ }^{16}$

Irish history authors meanwhile have been prone to the same error. Although some tend to ignore the perspective of the British authorities and so do not consider this issue, ${ }^{17}$ others repeat a brief version of the standard account, sometimes with modest modifications. ${ }^{18}$ Jeffery Dudgeon, in his 2002 study of Roger Casement and of Casement's 'black diaries', provides one of the longer accounts and again places signals intelligence at the centre of his narrative, quoting some of the telegrams printed in the 1921 volume in their entirety. 'There was also a wealth of detail gleaned from intercepts by Naval Intelligence', he writes, but of this 'plethora of information what actually ended up in Dublin Castle was negligible', and he again accuses Hall of suppressing the intelligence from the British authorities in Ireland. ${ }^{19}$

The only exception of any note is Benjamin Grob-Fitzgibbon's 2007 Turning Points of the Irish Revolution. In his two and a half page account of the run-up to the Easter Rising, Grob-Fitzgibbon curiously neglects to examine signals intelligence entirely, making no mention whatever of any of the intelligence historians above. He devotes only a paragraph to human intelligence sources. Grob-Fitzgibbon argues that the British suffered a 'failure of intelligence' and a 'failure of imagination by those tasked with collecting the intelligence'. Because the British were 'not expecting an assault on the state', they failed to 'look for any evidence that one was forthcoming'. While it may be said then that Grob-Fitzgibbon's account is the one the least disrupted by the research in this article, in some ways this is only because his account is so cursory. ${ }^{20}$

\footnotetext{
${ }^{10}$ O'Halpin, "British Intelligence in Ireland", 57-60, 64, 77.

11 Andrew, Secret Service, 246-247.

12 Andrew, "Casement and British Intelligence", 79.

13 Andrew, Defence of the Realm, 87.

14 Jeffery, 1916, 100-103.

15 Aldrich and Cormac, Black Door, 30-31.

${ }^{16}$ See for example McMahon, British Spies and Irish Rebels, 19-20; Walton, Empire of Secrets, 14-15; Boghardt, Zimmermann Telegram, 114; Northcott, MI5 at War, 169-170; Porter, Plots and Paranoia, 140-141; Delano, Guy Gaunt, 192. See also Larsen, "British Intelligence", 686; Hezlet, Electron and Sea Power, 112.

${ }^{17}$ See for example, McGarry, The Rising; Nowlan, ed., The Making of 1916; Kautt, The Anglo-Irish War; McHugh,

"Casement and German Help"; Inglis, Roger Casement, Edwards, 1916.

${ }^{18}$ See for example, Sawyer, Roger Casement's Diaries, 7; Cottrell, Anglo-Irish War, 32; McNally, Easter Rising 1916, 32.

${ }^{19}$ Dudgeon, Roger Casement, $459 \mathrm{ff}, 475$.

${ }^{20}$ Grob-Fitzgibbon, Turning Points, 100-103, 113. See also Kennedy, Genesis of the Rising, 266, 274.
} 
This then brings us to the only detailed study, from Geoff Sloan in his journal article 'The British State and the Irish Rebellion of 1916: An Intelligence Failure or a Failure of Response?' The first to engage with the question of British intelligence and the Easter Rising in depth, Sloan pens an otherwise impressive and well-considered piece that uncovers important new archival evidence. Unfortunately, however, Sloan takes as a given the assumption of previous authors and treats the telegrams in the 1921 volume as having all been decrypted contemporaneously. He places signals intelligence at the very centre of his analysis, quoting many telegrams printed in Documents Relative to the Sinn Fein Movement in their entirety. Although he considers human intelligence sources, these are seen are mere supplements to the vast amounts of signals intelligence he believed Room 40 had in their possession. Sloan criticizes O'Halpin and the other intelligence authors for their view that Hall suppressed intelligence, pointing to evidence of the sharing of Room 40 intelligence. Assuming then that this evidence of sharing encompassed the entire set of decrypts in the 1921 volume, Sloan shifts the blame onto the British authorities in Ireland and the British Cabinet, condemning them for failing to respond effectively to the intelligence. ${ }^{21}$

While Sloan's research is otherwise of a high quality, this underlying assumption compromises the very foundations of his argument. This article shows by contrast that only one short decrypt, not the full set, appears to have been in Room 40's possession before the Rising. While this one short decrypt was shared with the British civilian authorities in London and Dublin—and therefore Sloan's exoneration of Hall is correct - this decrypt provided only modest information. Sloan's harsh judgments of the civilian authorities, resting so heavily on the assumption that policymakers had vast amounts of signals intelligence in their possession, cannot now be supported on the basis of the evidence and argument that he presents. This is not to say, of course, that it is impossible to reach such a verdict: quite possibly it could be done through a more considered analysis of the human intelligence available or of other factors, about which this article makes no judgment. But Sloan rests his case principally on signals intelligence, and on that basis it cannot be sustained.

\section{THE TELEGRAMS}

To be sure, if Room 40 had possessed prior to the Rising all the decrypts included in the 1921 Documents Relative to the Sinn Fein Movement volume, as previous historians have believed, this certainly would have constituted an invaluable intelligence windfall. The volume lists eleven decrypts of telegrams about the Rising sent in two and a half months before it took place, which taken together certainly would have provided the 'comprehensive understanding' that Sloan claims. Of these eleven, five were central to arranging the German-Irish plot in February and early March, two dealt with relatively minor operational details in late March, and the final four centred around last-minute concerns and arrangements in the final week before the uprising. As these telegrams and their contents have been central to previous historical accounts and are key to understanding what signals intelligence the British did or did not possess, this section considers the contents of each. It reprints the text when it would have provided the British with vital intelligence if decrypted, and the telegrams are numbered one through eleven for convenient reference throughout the article.

The first five telegrams - the most important of the set-form the principal exchange in which the nature and most of the key details of the conspiracy were arranged. Sloan quotes all five in their entirety, treating all five as in Room 40's possession before the Rising. ${ }^{22}$ These five telegrams consist of an overture made by the Irish rebels to the German government, the German offer of assistance in reply, and the Irish

${ }^{21}$ Sloan, "British State".

22 Sloan, "British State", 470-472. 
acceptance of that offer. The first of these telegrams comes from an extract from a report dated 10 February, which was delivered to the German embassy, led by German Ambassador Count Johann von Bernstorff, ${ }^{23}$ and telegraphed to Berlin. The report was from Irish-American John Devoy, who acted as Germany's 'confidential agent' and intermediary in the United States with the Irish rebels.

\section{Telegram 1}

Unanimous opinion that action cannot be postponed much longer. Delay disadvantageous to us. We can now put up an effective fight. Our enemies cannot allow us much more time. The arrest of our leaders would hamper us severely. Initiative on our part is necessary. The Irish regiments which are in sympathy with us are being gradually being replaced by English regiments. We have therefore decided to begin action on Easter Saturday. Unless entirely new circumstances arise we must have your arms and munitions in Limerick between Good Friday and Easter Saturday. We expect German help immediately after beginning action. We might be compelled to begin earlier.

The second came a little over a week later, on 18 February, and was also from Bernstorff to Berlin. It consisted largely of a condensed, repeated summary of the previous telegram:

\section{Telegram 2}

The Irish leader, John Devoy, informs me that rising is to begin in Ireland on Easter Saturday. Please send arms to [arrive at] Limerick, west coast of Ireland between Good Friday and Easter Saturday. To put it off longer is impossible. Let me know if help may be expected from Germany.

The third telegram constituted Berlin's reply to the rebels' overture, sent on 4 March, and contained the full details of the planned German assistance, including the timing, location, and the precise details of the proposed rendezvous along with the full extent of the arms to be provided.

\section{Telegram 3}

Between $20^{\text {th }}$ and the $23^{\text {rd }}$ April, in the evening, 2 or 3 steam trawlers could land 20,000 rifles and 10 machine-guns, with ammunition and explosives at Fenit Pier in Tralee Bay. Irish pilot-boat to await the trawlers at dusk, north of the island of Inishtooskert at the entrance of Tralee Bay, and show two green lights close to each other at short intervals. Please wire whether the necessary arrangements in Ireland can be made secretly through Devoy. Success can only be assured by the most vigorous efforts.

The fourth and fifth telegrams formed the Irish acceptance of the German offer, with virtually identical contents. The fourth, sent on $12 \mathrm{March}$, was a disguised wireless message. '[T] ranslated it was:

\section{Telegram 4}

National Germania Insurance Contract certainly promised. Executor is evidently satisfied with proposition. Necessary steps have been taken. - Henry Newman’

Decoded it reads: -

'Irish agree to proposition. Necessary steps have been taken.'

The fifth telegram was sent from the German Embassy in Washington to Berlin, also on 12 March:

\footnotetext{
${ }^{23}$ See Doerries, Imperial Challenge.
} 


\section{Telegram 5}

Irish agree. Will follow instructions. Details sent to Ireland by messenger.

After these five telegrams outlining the plan of the Rising, there was an exchange of two further telegrams, dated a couple of weeks later, on 21 and $26 \mathrm{March}$, concerning operational details. Telegram 6, sent from Bernstorff to Berlin, provided a message from the Irish rebels suggesting a series of wireless codewords that Germany might use once the operation was underway, such as 'FINN' to mean that the ships were coming, and 'BRAN' to mean that something has gone wrong. Telegram 7, Germany's reply, in addition to confirming the wireless details, wrote that ' $[\mathrm{t}] \mathrm{hree}$ trawlers and a small cargo steamer are coming with 1,400 tons cargo-measurement. Lighters must be kept in readiness.'

Finally, the volume lists a further four telegrams as having been sent in the week before the Rising - a trio of last-minute messages, sent on successive days, from the Irish rebels asking to confirm details or requesting further German assistance, and lastly, a brief message in reply from Germany. The eighth telegram is dated 18 April, six days before the Rising:

\section{Telegram 8}

Delivery of arms must take place punctually on Sunday, 23rd April, in the evening. This is of the highest importance. As smuggling is impossible, the landing must be carried out rapidly.

The next telegram was dispatched from Bernstorff to Berlin the following day:

\section{Telegram 9}

The Irish desire to know if submarines are coming to Dublin Harbour; if not, do they intend to blockade the harbour and, if possible, Limerick Harbour?

The landing of a body of troops, however small, is urgently desired, and they further suggest a simultaneous strong demonstration by airships and at sea.

Bernstorff then followed this up with a further Irish request on 20 April, with Telegram 10 asking for 'an air raid on England and a naval attack timed to coincide with the rising, followed by a landing of troops and munitions'. The Foreign Office in Berlin replied to the submarine assistance request on Good Friday, 22 April:

\section{Telegram 11}

Sending of submarine to Dublin harbour impossible. ${ }^{24}$

Certainly, if Room 40 had had all of these telegrams in their possession before the Rising, the intelligence would have been both complete and invaluable. These decrypts would have provided: evidence of a detailed rebel assessment of the urgent need for early violent action, a request for German assistance, confirmation that considerable German assistance was being offered, rebel acceptance of the offered assistance, the precise details of the delivery of that assistance, and confirmation that the plot was going forward as planned. Moreover, by the mention of the dates '20-23 April' in the third telegram, the British authorities would have had good reason to wonder if the date might have changed from Easter Saturday

${ }^{24}$ Documents Relative to the Sinn Fein Movement, 9-13. See also Doerries, Prelude to the Easter Rising, 180-181, 185, 216219. Curiously, the 1921 volume omits a detailed, eleven-paragraph telegram about the planned Rising sent from Bernstorff to Berlin on 16 February 1916. As this telegram took three weeks to arrive, it appears to have been sent via the Swedish Roundabout. See Doerries, Prelude to the Easter Rising, 181-184. 
as mentioned in the initial telegram. (Easter in 1916 was on 23 April.) The eighth telegram, indeed, with its emphasis on landing the arms on the evening of 23 April, would have provided late but all but complete confirmation that the Rising was intended to take place the following day, Easter Monday.

If we accept the premise that British intelligence possessed these telegrams before the Rising, the savage judgments of previous historians are unavoidable: either British intelligence must have suppressed this information from the civilian authorities, or the civilian authorities must have grievously failed to act upon it. This article, however, contends that of the eleven telegrams above, only the second telegram can reliably be shown to have been in Room 40's possession before the Rising. The fourth telegram is at best uncertain, and in any case, given its contents and deprived of context, is unlikely to have been of much significance. All of the other telegrams almost certainly were not decrypted until after the Rising: as shown below, Telegram 5 does not appear to have been decrypted until October 1916 and Telegram 6 not until February 1917, and all of the other telegrams almost certainly were decrypted around that period.

This is to say, the advance diplomatic signals intelligence in British possession prior to the Rising can only reasonably be shown to consist in its totality of the four sentences of Telegram 2, which must now be considered in isolation:

The Irish leader, John Devoy, informs me that rising is to begin in Ireland on Easter Saturday. Please send arms to [arrive at] Limerick, west coast of Ireland between Good Friday and Easter Saturday. To put it off longer is impossible. Let me know if help may be expected from Germany. ${ }^{25}$

To be sure, these four sentences still provided crucial intelligence. But we have here only a rebel request for German assistance. Room 40 had no knowledge of whether German help was actually being provided or what the scale or details of that assistance might be. The only date mentioned for a possible rising is Easter Saturday, two days before it actually took place. There was no indication of whether the rebels' plans might have changed or indeed been called off altogether in response to Germany's reply. Room 40 had only a very small, albeit valuable, nugget of advance intelligence, not a treasure trove.

\section{GERMAN METHODS OF COMMUNICATIONS WITH THE UNITED STATES}

To untangle which of these telegrams Room 40 had decrypted at what times, the first step is to examine the communication methods used between Germany and its embassy in Washington. At this time, there were three means by which German messages were communicated to Berlin. The principal method of communication was the 'Swedish Roundabout', while two additional routes were the U.S. State Department and wireless radio communication between the United States and Germany.

These various indirect methods of communication were necessitated by Britain's virtually complete control over the transatlantic telegraph. Almost immediately at the war's outbreak, the British ship Alert severed Germany's Atlantic telegraph lines. ${ }^{26}$ Of the transatlantic cables that remained, most connected Britain or Ireland with the United States or Canada. The few exceptions included a pair of British cables and a French cable to Pernambuco, Brazil, 27 as well as then a pair of old French transatlantic cables from Brest to North America that 'never worked very well' and were widely avoided, since they had a terrible

\footnotetext{
25 Documents Relative to the Sinn Fein Movement, 10.

${ }^{26}$ Winkler, "Information Warfare", 848-849.

27 Winkler, Nexus, 10.
} 
reputation for 'very slow' transmission and hopelessly garbling messages. ${ }^{28}$ British cable censors subjected all telegrams that went over British cables to tight censorship, stopping any cable that seemed even a vague possible threat to the Allies' war efforts—a practice that swept up many innocent messages and provoked widespread neutral complaints. The use of encoded telegrams was strictly forbidden for private use, ${ }^{29}$ but even though they were under no legal obligation to do so, the British government nevertheless allowed neutral and allied governments to send encrypted telegrams over its telegraph lines. ${ }^{30}$

With the Allies having shut off Germany's telegraphic communications with its diplomatic outposts in the Americas from the outset of the war, Germany took advantage of its friendly relations with neighbouring neutral Sweden to gain covert access to Britain's telegraphic network. From practically the beginning of the war, the neutral Swedish had been secretly helping the Germans with their communications. At first, Bernstorff gave his messages directly to the Swedish ministry in Washington, which evaded British cable censorship by disguising them as Swedish diplomatic telegrams to Stockholm. The Swedish foreign ministry then retransmitted them to Berlin. In early 1915-before the political division of Room 40 had been created - the British Foreign Office had caught wind of this procedure and issued a complaint, bringing an abrupt halt to this practice. ${ }^{31}$ (Room 40 eventually returned to these early messages and decrypted them in 1918. $)^{32}$

The Swedes, however, continued to help the Germans by a more indirect route. First, Bernstorff would transmit his telegrams to Buenos Aires, Argentina. The Swedish legation there would then transmit the messages to Stockholm. Although we cannot be completely certain as to precisely which underwater telegraph line was used to send the messages across the Atlantic, the most logical route would have been to use the transatlantic British cables from Pernambuco, Brazil, to Britain, and thence from there using British cables across the North Sea. ${ }^{33}$ The possibility that some messages may have escaped British censorship using the French cable from Pernambuco to France cannot be completely excluded, but it is unlikely: to avoid Britain these messages would then have needed to have gone overland across France and then to use a French cable from Calais to Denmark. The French Calais-Denmark cable, however, 'was interrupted for long periods' and France's internal network was marred by 'great troubles' owing to a 'lack of experienced French operators' and the 'poor material of the French telegraph system'. ${ }^{34}$ The Foreign Ministry in Stockholm would then pass them on to Berlin. Messages in the other direction would be sent via the same route in reverse. This method came to be known as the 'Swedish Roundabout'which with its many stops was often a comparatively slow means of communications. ${ }^{35}$

The second method that the German embassy in Washington sometimes employed was to convince the U.S. government to transmit encoded messages to the German government via the American diplomatic posts in Copenhagen and Berlin. (American telegrams between Washington and its Berlin embassy were necessarily routed via Copenhagen, as direct telegraphic communications between the Allied and Central

\footnotetext{
28 See Winkler, Nexus, 17; Memorandum on Communications to and from Colonel House and Members of the American Mission and Washington, [1917], YUL: House Papers, 180:184; [U.K.] Report on Cable Censorship during the Great War (1914-1919), p. 10, NAC: Record Group 25 f8, Volume 1073, File \#81.

${ }^{29}$ Winkler, Nexus, Ch. 2.

30 See [U.K.] Report on Cable Censorship during the Great War (1914-1919), NAC: Record Group 25 f8, Volume 1073, File \#81.

${ }^{31}$ Nickles, Under the Wire, 141; Gannon, Inside Room 40, 133-135; Beesly, Room 40, 208.

32 See TNA: File ADM 137/3963.

33 Winkler, Nexus, 10.

${ }^{34}$ Larsen, "British Codebreaking"; Winkler, Nexus, 10; [U.K.] Report on Cable Censorship during the Great War (1914-1919), NAC: Record Group 25 f8, Volume 1073, File \#81; Memorandum on Communications to and from Colonel House and Members of the American Mission and Washington, [1917], YUL: House Papers, $180: 184$.

35 See TNA: File ADM 223/745; Gathen, “Zimmermann Telegram”, 13; Freeman, "Zimmermann Telegram

Revisited”, 130-133; Boghardt, Zimmermann Telegram, 91-94; Headrick, Invisible Weapon, 168.
} 
powers was not permitted. ${ }^{36}$ In conducting his negotiations with the American government over various matters, Bernstorff pointed out that he had no official means of communication with Berlin. If the Americans wanted to use him for their negotiations, he contended, they needed to transmit his telegrams for him. From time to time, in connection with the various controversies and other negotiations taking place between the two countries, the American government would allow him this method of communication. Most famously, the 'Zimmermann Telegram' of 1917, in which Germany offered Mexico the states of Texas, New Mexico, and Arizona if it would attack the United States, was transmitted using this route. In comparison with the Swedish Roundabout, this method was faster but was available only intermittently, and therefore could not be used for regular communications. ${ }^{37}$

The third method was to send radio messages from a German-owned radio transmission station at Sayville in Long Island to the German radio transmission station at Nauen, near Berlin. The American government, however, applied strict censorship and neutrality rules to radio communications stations, including a prohibition on encoded communications. When the Germans had been caught breaking these rules in mid-1915, the U.S. Navy took over the operation of the Sayville station. As a result, for anything but the most routine matters not requiring secure communications, this method could only be used for very short messages, which were rendered unintelligible to outside observers either by lack of context or by careful disguise to look innocuous but to have a secret meaning. ${ }^{38}$

\section{BRITISH DECRYPTION CAPABILITIES}

We must now compare these three methods of communications against British efforts to detect them. During the war, decryption duties were divided between two different agencies: Room 40 in the Admiralty and MI1(b) in the War Office. Room 40 was largely responsible for enemy naval and diplomatic codes, while MI1(b) worked partly on enemy army codes but largely on neutral and eventually allied diplomatic codes.

Even though these telegrams were eventually decrypted by Room 40, understanding MI1(b)'s efforts against neutral codes nevertheless is central to our understanding of which of these routes of communication the British were monitoring in early 1916. Initially tasked with solving German army codes, as the Western front became static and the Germans replaced their use of wireless radio with telegraph lines, MI1(b)'s original work 'practically dried up'. Instead, the group spent much of the remainder of 1915 working on solving American diplomatic codes, a task they appear to have completed sometime late that year. ${ }^{39}$ The following year was spent mostly on 'Greek, Swiss, and Spanish' codes; it was not until 1917 that the group turned its attention to Swedish telegrams, among others. ${ }^{40}$

With MI1(b) not yet breaking Swedish codes in 1916, Swedish telegrams-let alone Swedish telegrams to South America-would have seen no particular enhanced scrutiny until the thought occurred to Room 40 to examine them. All evidence points to the Swedish Roundabout not having been discovered by Room 40 until summer 1916. Quoting from a letter in his unpublished biography, Hall confirms that the Swedish Roundabout remained undiscovered as of May 1916:

\footnotetext{
${ }^{36}$ Larsen, "British codebreaking", 259.

${ }^{37}$ Gathen, "Zimmermann Telegram", 12-13; Freeman, "Zimmermann Telegram Revisited", 100-101; Boghardt, Zimmermann Telegram, 91; Tuchman, Zimmermann Telegram, 133; Nickles, Under the Wire, 219-220, n. 23.

${ }^{38}$ Winkler, Nexus, 26, 43-44, 51-52, Ch. 3; Von Zur Gathen, “Zimmermann Telegram”, 14; Headrick, Invisible Weapon, 168.

${ }^{39}$ Larsen, "British Codebreaking"; Bruce, "A Shadowy Entity".

${ }^{40}$ Freeman, "MI1(b)", 214; Official History of MI1(b), TNA: HW 7/35; Bruce, "A Shadowy Entity".
} 
It was a question which had been worrying us for some time past. How did [Bernstorff] get his telegrams to Berlin? 'We have traced nearly every route,' I had written to [British naval attaché to the U.S. Captain Guy] Gaunt at the beginning of May [1916], 'and I am really reduced to the following: he sends them down to Buenos Aires, thence across to Valparaiso. From there I cannot make out where they are sent, whether via China or Russia through the connivance of a neutral legation or not.' 41

According to Hall's unpublished autobiography, an intercepted letter from the German minister in Mexico to the German Chancellor, Theobald von Bethmann Hollweg, revealed Swedish complicity in arranging German communications between Washington and Berlin. A Swedish Chargé d'Affaires had been 'arrang [ing] the conditions for the official telegraphic traffic' with Berlin, and would 'every time, often late at night, personally...go to the telegraph office to hand in the despatches'. Hall continued,

It was clear that steps would have to be taken to have all Swedish Foreign Office cipher telegrams brought to us for examination. Arrangements were soon made for this to be done, and in many cases it was found that after a few Swedish groups our old friend 13040 [a long-cracked German code] would appear. Our excitement, moreover, may be imagined when through this means we discovered the route by which Bernstorff was communicating with his Government! ${ }^{42}$

It was the Buenos Aires to Stockholm leg of the Swedish Roundabout route that was the key one: on its way to Stockholm, the messages passed through Britain—meaning that the copies were waiting for Room 40 with the censor, only now they knew where to look. Surviving decrypts in Admiralty files corroborate Hall's account and make it reasonably clear that it was only in late July to mid-August 1916 that Room 40 finally came to grips with the problem. ${ }^{43}$ Many of the decrypts surviving in Admiralty files have both a date of original dispatch and a date of decryption. The earliest date of decryption of a Swedish Roundabout telegram to survive in British archives is a 28 July 1916 decrypt of a telegram dated 17 July. Swedish Roundabout telegrams from earlier in July were not decrypted until later: a telegram dated 7 July was decrypted on 4 August; a telegram from 13 July was decrypted on 7 August. ${ }^{44}$

The earliest archival reference outside of the files of decrypts, moreover, comes from the diary of Maurice Hankey, the influential secretary to the War Committee, who records a 25 August 1916 conversation with Arthur Balfour, the First Lord of the Admiralty and Hall's superior, and which appears to refer to German telegrams dated 22 June and 18 August: 45

the German foreign office communicated with the United States via Sweden, the Swedish Foreign Office forwarding their messages, sometimes through Russia ${ }^{46} \&$ sometimes through England. As we had got their cipher we knew exactly what was passing. E. G. we now knew for a fact that Bernsdorf [sic] had most solemnly told Germany that their submarine blockade must cease, or the U.S.A. would inevitably be drawn into the war. Also that the German Foreign

\footnotetext{
${ }^{41}$ Quoted in Draft “D”, Chapter 25, Hall unpublished autobiography, p. 2, CCAC: Hall Papers, HALL $3 / 6$.

${ }^{42}$ Draft "D", Chapter 25, Hall unpublished autobiography, pp. 4-6, CCAC: Hall Papers, HALL 3/6; Beesly, Room $40,210$.

43 See TNA: files ADM 223/745, ADM 223/774, ADM 223/776. Peter Freeman, relying only on file HW 7/7, put this date at around 14 September 1916. The Admiralty files and Hankey's diary prove that this actually took place earlier. See Freeman, "MI1(b)", 213; Freeman, “Zimmermann Telegram Revisited”, 132.

${ }^{44}$ Stockholm to Buenos Aires Swedish Decrypts, 28 July, 4, 7 August 1916, TNA: ADM 223/774.

45 Official German Documents, 979, 981-982.

46 Why Hankey believed that the cables were sometimes routed through Russia is unclear. There is no telegraph route from Buenos Aires to Stockholm via Russia, rather than Britain, that would make much sense-the only two transpacific cables originated on the west coasts of the United States and Canada. See Winkler, Nexus; Burns, "Submarine Cable Route Maps"; Headrick and Griset, "Submarine Telegraph Cables". Nor is there any intelligence documentation that supports the idea that some of the telegrams went via a Russian route.
} 
Office had told Bernsdorf to keep in friendly relations with President Wilson in order to secure his intervention when required. ${ }^{47}$

It was not until October and November of 1916 that Room 40 turned its attention to earlier dispatches, generating a mass of decrypts of telegrams from earlier in 1916- which would have included those of the telegrams above relating to the Easter Rising that were sent via this route. ${ }^{48}$

While telegrams sent via the Swedish Roundabout escaped Room 40's notice in early 1916 because no one was scrutinizing Sweden's South American communications, German telegrams sent via the U.S. State Department would have attracted British attention because of MI1(b) activities against American codes. From at least late 1915 onwards, MI1(b) was carefully scrutinizing American transmissions. Any attempt by the U.S. government to pass along encoded German telegrams could not have escaped the military intelligence organization's notice, and MI1(b) would have been able to flag up any such telegrams for Room 40-especially as the telegrams would have contained an unmistakable header in an American code instructing the American ambassador in Berlin to pass on the encoded German telegram to the German government. ${ }^{49}$ There is good evidence, moreover, of MI1(b) and Room 40 cooperating in this regard. Inquiries survive dated as early as July 1915 from MI1(b) to Room 40 about German codes it was unable to solve. ${ }^{50}$ We know, moreover, that Hall was in receipt of MI1(b) American decrypts as early as January $1916 . .^{51}$

Peter Freeman briefly seizes on a fragment of evidence to claim that Room 40 only began decrypting German telegrams sent along the American route in September 1916, but it seems almost certain that he has misinterpreted the document. One of the Room 40 cryptanalysts, Nigel de Grey, wrote in a minute to Hall on 21 September 1916, a carbon copy of which was given to MI1(b):

Further, it is now abundantly clear that telegrams are passing to Washington not intercepted by us and not transmitted via Buenos Aires. Neither can the telegrams omitted from our series be fitted into the wireless messages from Sayville or Tuckerton - their number is by no means large enough. I consider it likely that they are sent via the State Dept. and the U.S.A. Embassy and might consequently be interceptable there.

Freeman himself acknowledges that his interpretation of this is deeply puzzling: it is not clear why MI1(b) had not already spotted' the German telegrams in the American telegrams that they were decrypting. ${ }^{52}$ Given the inquiries that passed between the two organisations in 1915, this interpretation would require us to believe that MI1(b) decrypted headers of telegrams instructing the American Ambassador in Berlin to pass on a following encoded German telegram to the German Foreign Ministry, and that MI1(b) then did absolutely nothing with them-despite sending on other American decrypts to Room 40. Then, we are to believe, in September 1916, the idea brilliantly and spontaneously occurred to a Room 40 cryptographer that there might be German telegrams sent via the State Department, and from then on MI1(b) started passing on the messages. Adding additional context to de Grey's minute makes this improbable explanation even more unlikely. The first half of de Grey's minute reads:

I append list of Buenos Aires telegrams not received, giving the number of cablegrams missing between certain dates. May further search be made for these please. It is clear that they are not in the unknown cypher as the dates of receipt... do not correspond with our list.

\footnotetext{
${ }^{47}$ Hankey Diary, 25 August 1916, CCAC: HNKY 1/1.

48 See TNA: files ADM 223/745, ADM 223/774, ADM 223/776.

${ }^{49}$ Larsen, "British Codebreaking".

${ }^{50}$ Exchange of letters between Room 40 and MI1(b), 1915, TNA: HW 3/184.

${ }^{51}$ Larsen, "British Intelligence". See also Larsen, "War Pessimism".

52 Freeman, "MI1(b)", 213; de Grey minute, 21 September 1916, TNA: HW 3/184.
} 
The previous day, moreover, de Grey had complained in a minute to Hall of problems with the Cable and Censor's Offices: 'May they be warned once more to be more accurate', he wrote, asking whether it was 'possible that it is in the copying in the censor's office that mistakes occur and not in the cable office?'53 Only six months later Hall was renewing de Grey's complaint: 'on at least one occasion lately it has been necessary to ask for further search to be made for certain telegrams which had escaped [the Cable Censor's] notice', Hall wrote, demanding that 'steps... be taken to remedy any further delays'. ${ }^{54}$

These give a basis for a much likelier and more pedestrian interpretation for de Grey's minute. Rather than it reflecting a crucial moment of discovery and a turning point in Room 40's capabilities, instead, about two months after the discovery of the Swedish Roundabout, de Grey was methodically trying to ascertain that Room 40 had tracked down all of the German telegrams that had relatively recently been sent between Washington and Berlin. In so doing, he had found plenty of instances in which encoded Swedish telegrams were not passed on to Room 40 because of errors at the Cable or Censor's Offices. His tally, moreover, revealed further discrepancies of missing telegrams that he was unable to account for. He therefore was merely suggesting that a meaningful number of the missing telegrams might have been sent via the long-discovered State Department route, and had simply gotten lost at some point in their journey to Room 40 through the Cable Office, the Censor's Office, and MI1(b). A textual analysis of the intelligence later in this article provides further corroboration of this interpretation.

Finally, virtually nothing is known about British decryption efforts against German diplomatic wireless radio communications with the United States, with no relevant material seeming to have survived in British archives. Even so, given the nature of the communications, there is reason to suspect that the codebreaking may have taken some time, and even that any 'decrypts' of messages sent via this route may well have been simply a matter of deduction much later in retrospect. With so few and so short of messages being sent in this way, discerning their meaning, particularly at the time the messages were sent, cannot have been easy, or for Room 40 to have had much confidence in their interpretation except in conjunction with other intelligence and after the fact.

In sum, only those German telegrams not sent via the Swedish Roundabout are in contention for having been decrypted before the Rising, and only those sent via the U.S State Department are probable.

\section{ANALYZING THE TELEGRAMS}

Although the evidence on the relevant eleven telegrams printed in Documents Relative to the Sinn Fein Movement is limited, the indications that exist support the idea that only one of the eleven telegrams can reasonably be shown to have been decrypted by British intelligence prior to the Rising. The volume provides clear information as to the route of communications for only two of the telegrams-identifying one as having been sent via the State Department and one as having been sent via wireless-while providing no information on any of the others. The most probable interpretation is that the remaining nine telegrams were all sent only via the Swedish Roundabout and therefore not decrypted before the Rising.

The Documents Relative to the Sinn Fein Movement volume provides clear information on the routes of communications for Telegrams 2 and 4 . The volume confirms that Telegram 4 was 'a code message in German...sent by wireless from the German Embassy in Washington to Banker Max Moebius, Oberwallstrasse, Berlin'. The volume also confirms that Telegram 2 was 'attached surreptitiously by

${ }^{53}$ De Grey minutes, 20 and 21 September 1916, TNA: HW 3/184. Emphasis in original.

${ }^{54}$ Hall to French, 30 March 1917, TNA: HW 3/184. 
Count Bernstorff to a message regarding the "Lusitania" negotiations, which was sanctioned and passed through by the State Department of the American Government'. ${ }^{55}$ Moreover, the telegram was sent by Bernstorff on 17 February and arrived at the German Foreign Office on 20 February, a speed consistent with its having been sent via the Americans. ${ }^{56}$ Given that this telegram was passed via the State Department, and the fact that MI1(b) is known to have been breaking American codes at this time, it seems highly likely that the telegram would have been processed by MI1(b), who would have had every opportunity to pass the telegram onto Room 40 for decryption.

For the remaining telegrams, the most reasonable conclusion is that they were all transmitted via the Swedish Roundabout, the details of which the British government in 1921 still worked to conceal, with the published volume mentioning nothing about it — the volume begins with a statement that it sought not to 'disclos[e] sources of information [or] channels of communications'. ${ }^{57}$ The fact that the volume identifies Telegram 2 as 'passed through by the State Department', however, is highly notable. If the U.S. government had noticed, it might have caused diplomatic tumult between Britain and the United States, with its clear implication that the British government had been scrutinizing and decrypting American diplomatic telegrams. That the compilers of the volume took such evident pains to identify any telegram with a transmission method other than the Swedish Roundabout - even when that identification inadvertently revealed an even more sensitive secret-itself seems a reasonable indicator that those not otherwise marked were sent via the Swedish government.

Of these nine telegrams likely to have been sent via the Swedish Roundabout, there is good independent evidence that seems to confirm this for seven of them: the original decrypts of two survive, and information about five further telegrams appears in published German documentation. A decrypt of Telegram 5 survives in a cache of Admiralty decrypts of German telegrams sent from Buenos Aires to Stockholm. This decrypt confirms that the telegram was sent via that route, and the date at the top of the document is 30 October 1916 - almost certainly the date of decryption..$^{58}$ A decrypt of Telegram 6 also survives in a separate cache of 'Irish Papers' retained by the British government until 2009. It does not identify the route of transmission, but the date at the top of the document is 2 February 1917, again most probably the date of decryption..$^{59}$ Moreover, from German documentation, we know that Telegram 1, though it was dispatched on 10 February, did not arrive at the German Foreign Office until 7 March, a delay consistent only with the Swedish Roundabout. This documentation also confirms unambiguously that Telegrams 8, 9, 10, and 11 were all sent via Buenos Aires. ${ }^{60}$

The wireless telegram, Telegram 4, is a somewhat difficult case, but while it is not impossible that Room 40 had deciphered its meaning, it is at best uncertain. Consider more closely the encoded text of the message:

National Germania Insurance Contract certainly promised. Executor is evidently satisfied with proposition. Necessary steps have been taken. - Henry Newman

Resolving the meaning of this telegram requires Room 40 to have been able to identify, or at least guess, that 'the National Germania Insurance Contract' refers to Germany's offer for military assistance to the planners of the uprising, and that the 'Executor' referred to those planners. Given the infrequency and brevity of these sorts of encoded wireless messages, it is unclear how Room 40 might have established

\footnotetext{
55 Documents Relative to the Sinn Fein Movement, 10.

${ }^{56}$ Doerries, Prelude to the Easter Rising, 185; Telegram AS 621, No. 675, NLI: MS14,914 (vol. 2).

${ }^{57}$ Documents Relative to the Sinn Fein Movement, 2.

${ }^{58}$ Washington to Berlin Decrypt, 12 March/30 October 1916, TNA: ADM 223/745.

${ }^{59}$ Washington to Berlin Decrypt, 15 March 1916/2 February 1917, TNA: ADM 223/671.

${ }^{60}$ Doerries, Prelude to the Easter Rising, 180-181, 216-219.
} 
this with any confidence without additional information, especially in the absence of any knowledge of the German offer itself. By contrast, the added context that would later have been provided by the Swedish Roundabout decrypts would make the meaning of the message immediately plain—most obviously from the fact that Telegram 5 was sent on the very same day and with an identical meaning: 'Irish agree. Will follow instructions.' 61

Having established that Telegram 2 is the only telegram whose encoded copy is likely to have been detected by Room 40 prior to the Rising, we now turn to the question of the telegram's decryption. A decrypt of Telegram 2 appears in the cache of surviving decrypts of telegrams sent from Buenos Aires to Stockholm, though that this decrypt survives in the Buenos Aires-Stockholm file appears to be a mistake. The text provides no route of transmission information; the only indication of a route is that the decrypt is marked with 'BA' (Buenos Aires) in pencil, which is almost certainly an error added in after the fact. The telegram referred to by this article as Telegram 2 was originally dispatched as German Telegram No. 675. This short telegram was appended to the much lengthier Telegram No. 674, which dealt with the Lusitania crisis and is why the American government was willing to forward it on to Berlin. Bernstorff dispatched the two telegrams together, sending them as a single block, so as to disguise the extra telegram from the eyes of the U.S. State Department code clerks whose responsibility it would have been to transmit it originally. A handwritten note in pen at the end of the decrypt reads, 'It will be observed that this Irish message is appended to the other so that all may look like one message.'

This decrypt says that the original Telegram No. 674 was sent in 'Cipher 0064'; there is no indication of the code of Telegram No. 675.62 Code 0064 was what Room 40 referred to as a 'hatted' code- that is, a 'two-part code' in which each plaintext word was assigned a random codeword, as if the codeword had been drawn randomly out of a hat. (These were distinguished from one-part codes, a type of codebook in which code clerks both encoded and decoded telegrams using the same volume-this meant that a onepart code had to be constructed alphabetically, which significantly reduced the security of the code.) According to an internal history, Room 40's first efforts against a hatted code were directed against Code 0064. 'Code No. 64...came into current use in March 1915, was worked at...during the autumn and winter of 1915-16, was taken over by the special staff in May 1916 and became readable in the course of the summer. ${ }^{63}$ The date at the top of the decrypt is 28 October $1916 .{ }^{64}$

However, this internal history also has a section entitled 'Military Satzbuch and Ireland'. Discussing Room 40 efforts against encoded German wireless telegrams sent between Nauen and Madrid (unlike the Americans, the Spanish did not have wireless neutrality regulations), the history writes:

One of its incidental results was the decoding of the very valuable correspondence between the military authorities and the military attaché at Madrid. A message containing certain instructions suggested the alphabetical arrangement of the military code (Satzbuch) and Mr. Mair working on these lines reconstructed it. This code and its concomitant cypher became readable in time to give nearly a month's warning of the plans for the Easter insurrection in Ireland communicated from America. ${ }^{65}$

A superficial reading of this passage gives the possible interpretation that it was the Madrid-Berlin wireless link that was important for the decryption of the relevant telegram. However, the text itself says

\footnotetext{
${ }^{61}$ Documents Relative to the Sinn Fein Movement, 10-11.

62 Washington to Berlin Decrypt, 17 February/28 October 1916, TNA: ADM 223/745.

${ }^{63}$ George Young, Political Branch of Room 40 Memorandum, [c. 1918], pp. 3-4, TNA: ADM 223/773.

${ }^{64}$ Washington to Berlin Decrypt, 17 February/28 October 1916, TNA: ADM 223/745.

${ }^{65}$ George Young, Political Branch of Room 40 Internal History, [c. 1918], p. 2, TNA: ADM 223/773.
} 
only that the wireless link was important to the solving of the Satzbuch code, and that it was the Satzbuch code-not the wireless link - that was central to giving 'a month's warning of the plans for the Easter insurrection'. Adding to this is that it makes no sense for any German telegrams from Washington to have used the Madrid wireless link: as mentioned above, the only telegraph lines connecting Spain to the Americas were British and French, so Swedish participation would still have been necessary to evade telegraphic censorship. The Swedes would have had no reason to send German telegrams from Buenos Aires to Madrid, instead of to Stockholm. Of the German Berlin-Madrid decrypts that survive, moreover, none feature any telegrams to or from Washington. ${ }^{66}$

If we take this much likelier reading of the above passage from the internal history-connecting only the solving of the Satzbuch code, and not the German-Madrid wireless link, to giving warning of the Easter Rising - a coherent interpretation that accounts for all of the evidence now presents itself. While Telegram No. 674 was sent in code 0064, which was unreadable until summer 1916, and was not decrypted until October, Telegram No. 675 was actually sent in the Satzbuch code, which was broken much earlier in 1916. Given the very different contents of the two telegrams, it is not surprising that the Lusitania telegram would be sent in a diplomatic code, while the telegram asking for military assistance for the Irish rebels would be sent in a military code. Room 40 noticed that the the telegrams were sent in different codes, and the latter telegram was decrypted a month before the Rising.

Increasing the likelihood of this interpretation, the original German copy of the latter telegram, while unfortunately containing no indication of the code in which the telegram had been sent, is marked 'Communicated to Captain [Rudolf] Nadolny'. Nadolny, head of Department IIIb of the German General Staff, which was generally responsible for German espionage activities, had been put in charge of communication with Casement and of coordinating matters relating to Casement with the Foreign Office and other government departments from November 1914. He had been coordinating matters related to Casement with the German Embassy in Washington as early as January 1915, and Telegram 3 in reply had been drafted by him personally. ${ }^{67}$ Given Nadolny's role at the centre of events, it is logical that a telegram involving communication with him would be sent in a code also used by military attachés, rather than in a purely diplomatic code.

\section{COMPARATIVE TEXTUAL ANALYSIS AND ROOM 40 NAVAL WIRELESS DECRYPTION}

The best indications from what we can learn about the telegrams, their modes of transmission, and British interception and decryption efforts all suggest that only Telegram 2 has any likelihood of having been in British possession before the Rising. Applying a careful comparative textual analysis to British archival evidence referring to the intelligence provides a strong independent test of this hypothesis and appears to confirm it. Three separate documents concerning intelligence provided to British policymakers in London or Dublin are known to have survived. Comparing their contents with those of the telegrams above provides further strong evidence for this article's fundamental assertion. Two of these texts also appear to demonstrate that two further very small nuggets of intelligence appear to have been obtained by Room 40 prior to the Rising. This section contends that these further nuggets were derived from Room 40 's naval wireless codebreaking activities, rather than from its diplomatic capabilities.

\footnotetext{
${ }^{66}$ See for example, files TNA: ADM 223/737, ADM 223/738.

${ }^{67}$ Doerries, Prelude to the Easter Rising, 63-64, 81-82, 186. The original German copy of Telegram 2 has been fully and faithfully transcribed and translated by Doerries, and it contains no further information about the code of transmission. See Telegram AS 621, No. 675, NLI: MS14,914 (vol. 2).
} 
The argument above is that Telegram 2 was sent via the U.S. State Department in the Satzbuch code. MI1(b) is known to have been monitoring U.S. State Department transmissions from late 1915, and according to the internal history, Room 40 solved the Satzbuch code 'in time to give nearly a month's warning of the plans for the Easter insurrection', i.e., in late March 1916. ${ }^{68}$ The earliest of the three British documentary texts matches precisely that timeline, consisting of a record from 23 March 1916. This text was first uncovered by Sloan and is contained in a memorandum found in the Asquith papers. Recall again the contents of Telegram 2:

The Irish leader, John Devoy, informs me that rising is to begin in Ireland on Easter Saturday. Please send arms to [arrive at] Limerick, west coast of Ireland between Good Friday and Easter Saturday. To put it off longer is impossible. Let me know if help may be expected from Germany. ${ }^{69}$

By comparison, the memorandum in the Asquith papers reads:

On the 23 ${ }^{\text {rd }}$ March, 1916, the Director of Military Intelligence informed General Headquarters, Home Forces, that he had received information from an absolutely reliable source that a rising in Ireland was contemplated at an early date, and that extremists in that country were in communication with Germany with a view to obtaining German assistance. He added that the rising was timed to take place on 22 $2^{\text {nd }}$ April [Easter Saturday] and that Irish extremists has asked Germany to supply arms and ammunition in Limerick by that date. Acting on similar information the Admiral at Queenstown issued a stringent order for the patrolling of the Irish Coast. ${ }^{70}$

The similarities between these two texts are utterly striking, with every single piece of information in Telegram 2 present and communicated in the memorandum. What is also striking about this memorandum, however, is that despite being issued in late March, it makes no mention of any of the information contained in the other five telegrams that by then had been sent. It contains no reference to the 'Irish regiments being replaced by English regiments' as in Telegram 1, to the precise details of the offered German assistance in Tralee Bay (as opposed to Limerick) set out in Telegram 3, to the Irish acceptance of the German offer in Telegrams 4 and 5, or to the wireless arrangements detailed in Telegram $6 .{ }^{71}$

The second text is from the Queenstown Garrison Commanding Officer Brigadier General W. F. H. Stafford, who wrote on Easter Saturday:

On Sunday the 16th [April] inst I received information that two German submarines either alone or escorting a ship disguised as a tramp steamer left Germany on the $12^{\text {th }}$ inst with a view to landing arms and ammunition on the SW Coast of Ireland. It was further stated that the arms etc were to be conveyed to Limerick and that a rising was timed for Easter Eve [today]..$^{72}$

The first half of the passage contains new information concerning the movements of German ships. The second half of the passage is entirely consistent with the intelligence contained in Telegram 2-and again, only that telegram and not any of the other ten, with its references to 'Limerick' and not 'Tralee Bay', and to 'Easter Eve' and not 'between the $20^{\text {th }}$ and the $23^{\text {rd }}$ April'. The likeliest interpretation is that an additional small piece of important signals intelligence was produced by Room 40 in the first half of the statement, which was then combined with the information contained in Telegram 2.

\footnotetext{
${ }^{68}$ George Young, Political Branch of Room 40 Internal History, [c. 1918], p. 2, TNA: ADM 223/773.

${ }^{69}$ Documents Relative to the Sinn Fein Movement, 10.

${ }^{70}$ Memorandum, BODL: Asquith Papers, Box 42, Folder 5-9, quoted in Sloan, "British State", 473.

${ }^{71}$ Documents Relative to the Sinn Fein Movement, 9-11.

72 Stafford Letter, 22 April 1916, BODL: Nathan Papers, MS 476, quoted in Sloan, "British State", 472.
} 
Room 40's interception and decryption of German naval wireless signals is by far the likeliest source of this additional intelligence on the German ship movements. This information is unlikely to have come from diplomatic signals intelligence or human intelligence, owing to the simple reason that the Irish rebels appear not to have known whether there would be any submarine participation in the uprising at all. The only ship details contained in the 1921 volume, after all, refer (inaccurately) to 'three trawlers and a small cargo steamer', from Telegram 7 on 26 March. None of the telegrams sent from Berlin make any mention of submarines, apart from the final one simply mentioning that one would not be coming to Dublin harbour. Recall, moreover, the utter lack of knowledge the Irish rebels had about German submarine participation as shown in Telegram 9, from Bernstorff to Berlin on 19 April: 'The Irish desire to know if submarines are coming to Dublin Harbour; if not, do they intend to blockade the harbour, and, if possible, Limerick Harbour??73

Excluding the possibility that this information on ship movements came from diplomatic decryption, the only plausible remaining candidate for the source of this new information is Room 40's operational wireless naval decryption efforts. Although Room 40's wireless interception and decryption efforts are poorly studied in general, what we know is sufficient to make this a highly probable explanation. A significant wireless interception service, with stations around the country, fed intercepted wireless messages into Room 40, which was able to decrypt them. These decrypts, in combination with directionfinding techniques, allowed Room 40 to keep a reasonable but imperfect eye on the German Admiralty's surface fleet and U-boats whenever they made use of their wireless. ${ }^{74}$

The extent to which Room 40 was able to offer information on the location of German U-boats in the lead up to the Battle of Jutland, demonstrate British capabilities in this regard around this time. From 16 to 23 May 1916, Room 40 detected a large movement of U-boats departing Germany. Yet the British Admiralty assumed that these were moving to attack British trade routes, instead of realizing that they were taking up forward positions to provide advance cover for a sortie of the German surface fleetdemonstrating at once both the ability of wireless decrypts to provide important intelligence, but also the vagueness of the information they sometimes generated..$^{75}$

We very much see these elements at play in the intelligence provided to Stafford: 'two German submarines either alone or escorting a ship disguised as a tramp steamer left Germany on the $12^{\text {th }}$ inst'. ${ }^{76}$ We see a certainty of the date of departure and in the number of submarines, but vagueness in everything else. This lends credence to the notion that Room 40 decrypted some uncertain snippet of German naval wireless communications involving the submarines, and then it combined that new piece of the puzzle with Telegram 2 to conclude that the assistance requested in that telegram was in fact being provided and the operation underway.

This same information was conveyed in the third text that survives, with one small change. This text came from the appendix to the official commission of inquiry into the rebellion, which recorded that on

the 17th of [April 1916]...the Under Secretary at the Castle [was shown] a letter from the Officer Commanding Queenstown defences which told of a contemplated landing from a German ship, rigged up as a neutral and accompanied by two submarines, of arms and ammunition on the south-west coast with a view to their reaching Limerick, and of a rising timed for Easter eve. ${ }^{77}$

\footnotetext{
${ }^{73}$ Documents Relative to the Sinn Fein Movement, 12.

${ }^{74}$ See Grant, U-Boat Intelligence; Andrew, Secret Service, Ch. 3; Santoni, "First Ultra Secret".

${ }^{75}$ Hines, "Sins of Omission", 1125.

${ }^{76}$ Stafford Letter, 22 April 1916, BODL: Nathan Papers, MS 476, quoted in Sloan, "British State", 472.

77 Minutes of Evidence, 7.
} 
We see again combination of the information about two submarines with the information consistent with Telegram 2. As before, the intelligence mentions only 'Limerick' and 'Easter eve', and no information contained in any of the other diplomatic telegrams is present. Now, however, the information about ' $a$ German ship, rigged up as a neutral' seems to be communicated with greater certainty; this appears to be accounted for by an additional wireless intercept. According to an internal history of Room 40, there was a fragment of a wireless signal intercepted on 15 April 1916 from Nauen, which consisted of an incomplete sentence: 'whether German auxiliary cruiser vessel, which is to bring weapons to Ireland has actually'. This fragment appears to have allowed Room 40 to confirm that the two submarines were in fact being accompanied by a German ship carrying munitions. ${ }^{78}$

This textual analysis provides further independent evidence that, contrary to claims throughout the existing historiography, only Telegram 2, and not any of the other telegrams, is likely to have been decrypted by Room 40 prior to the Rising.

\section{IMPLICATIONS AND CONCLUSION}

While attempting a full re-interpretation of the intelligence available to the British authorities before the Rising and of the British response to the Rising is beyond the scope of this article, some key implications can nevertheless be addressed.

First, the notion of a failure to share intelligence may be put fully to rest. Sloan is certainly correct in his challenge to previous historians when he dismisses the widely repeated notion that Hall purposefully suppressed the signals intelligence available to him. The above makes clear that Room 40 almost certainly circulated all of the very limited signals intelligence at its disposal — a circulation that appears to have been central to the British navy's success in having effective and alert patrols on the Irish coast that were able to intercept the German guns meant for the Rising. Yet the assumption present in much of the historiography, that the British were simply lying in wait to spring a trap on the hapless German operation, is also clearly mistaken. Rather, as the British government had no access to precise details, the role of sheer luck in the fact that eagle-eyed crew of the HMS Bluebell spotted and challenged the suspicious German vessel carrying arms for the Rising should not be underestimated. The intelligence was important, but it was no substitute for good naval practice.

Nor, at least with signals intelligence, can it reasonably be contended that there was a failure of intelligence. Room 40 both collected and shared all of the intelligence that it might have been expected to collect. While an argument might be made that they should have figured out the Swedish Roundabout sooner, such an argument would be based entirely on the wisdom of hindsight. There was a reason why the Germans and the Swedes decided to route German messages between Washington and Berlin via Buenos Aires and Stockholm: it was profoundly unexpected and would, not unreasonably, take the British a long time to track down. Indeed, in many ways the British were profoundly lucky that the Lusitania crisis between the U.S. and Germany flared up again precisely when it did in February 1916. If Telegram 2 had been routed via the Swedish Roundabout instead of the U.S. State Department, Room 40 would have had even less warning to provide and the German-Irish conspiracy might well have had much greater success.

Additionally, this clarifies certain statements and actions of key British figures, particularly on the important legal question as to whether the Irish rebels were actually in league with Germany-and whether therefore the 1914 Defence of the Realm Act could be brought to bear against them. Sloan all but accuses Undersecretary of Ireland Sir Matthew Nathan of lying when Nathan asserted that 'Until

${ }^{78}$ Birch and Clarke Room 40 History, TNA: HW 7/3; Beesly, Room 40, 187. 
three days before the insurrection there had been no definite proof of any connection between the antiBritish party in Ireland and the foreign enemy.' Taken by Sloan as evidence of either idiocy or mendacity on Nathan's part, ${ }^{79}$ in reality the only proof the British possessed well in advance of the Rising was that of an Irish-American's solicitation of German assistance. The British had no firm proof of collaboration between the German government and rebel actors in Ireland until Casement's arrest and the scuttling of the Aud. Similarly, Sloan writes that the Royal Commission investigating the Easter Rising was 'deficient' and 'unbalanced' in its ignoring of signals intelligence and therefore in its missing of the largest pieces of the intelligence puzzle..$^{80}$ In focusing its attentions on human intelligence, however, the Royal Commission reveals itself better grounded than the historians who would write on this topic over the next century.

While this article does not venture so far as to assert what should now stand in the place of the narrative that the article sweeps away, it is clear that human intelligence must now be placed at the centre of any subsequent intelligence study of this topic. Sloan treats the human intelligence reporting of sources Chalk and Granite as supplementary sources of yet further information on a conspiracy that British signals intelligence had already entirely unravelled..$^{81}$ With such limited signals intelligence however-and with it wrongly pointing to Easter Saturday instead of Easter Monday-the human intelligence that was being provided to the British authorities in reality constituted almost all of the intelligence then in British possession. Any accurate narrative of British intelligence and the Easter Rising must now focus most of its attention on Chalk and Granite; the role of Room 40 has been shown to be clearly much smaller than previously believed.

Above all, however, this article demonstrates the profound care that must be applied to signals intelligence evidence. Often fragmentary and lacking in vital details - in this case the crucial date of decryption - it must be subjected to the most rigorous analysis if it is to be employed reliably. For this episode, one small but key unsubstantiated supposition about the evidence was made, and it has led to decades of confusion. Many mistaken conclusions have been built on an utterly errant premise. This article has aimed to correct that premise and to provide at last sound foundations for renewed investigation.

\section{ARCHIVAL RECORDS}

Bodleian Library, Oxford (BODL): Asquith Papers

Churchill College Cambridge Archive Centre (CCAC): Hall Papers, Hankey Papers

The National Archives (UK) (TNA): series ADM 137, 223, HW 3, 7

National Archives Canada (NAC): Record Group 25 f8

The National Library of Ireland (NLI): MS 14,914

Yale University Library (YUL): House Papers

\footnotetext{
79 Sloan, "British State", 477-478, 481, 491.

80 Sloan, "British State", 491.

81 Sloan, "British State", 481-484.
} 


\section{REFERENCES}

Aldrich, Richard and Rory Cormac. The Black Door: Secret Intelligence and 10 Downing Street. London: William Collins, 2016.

Andrew, Christopher. "Casement and British Intelligence" in Roger Casement in Irish and World History, Mary E. Daly (Ed.). Dublin: Royal Irish Academy, 2005.

Andrew, Christopher. The Defence of the Realm: The Authorized History of MI5. London: Penguin, 2009.

Andrew, Christopher. Secret Service: The Making of the British Intelligence Community. London: Heinemann, 1985.

Beesly, Patrick. Room 40: British Naval Intelligence 1914-1918. London: Hamish Hamilton, 1982.

Boghardt, Thomas. The Zimmermann Telegram: Intelligence, Diplomacy and America's Entry into World War I. Annapolis: Naval Institute Press, 2012.

Bruce, James. “"A Shadowy Entity': M.I.1(b) and British Communications Intelligence, 19141922". Intelligence and National Security 32, no. 3 (2017): 313-332.

Burns, Bill. "Submarine Cable Route Maps.” History of the Atlantic Cable \& Undersea Communications Website. Last accessed 3 February 2017. http:/ /www.atlanticcable.com/Maps/index.htm

Coogan, Tim Pat. 1916: The Easter Rising. London: Cassell, 2001.

Costello, Francis J. “The Role of Propaganda in the Anglo-Irish War 1919-1921.” The Canadian Journal of Irish Studies 14, no. 2 (1989): 5-24.

Cottrell, Peter. The Anglo-Irish War: The Troubles of 1913-1922. Oxford: Osprey, 2006.

Delano, Anthony. Guy Gaunt: the Boy From Ballarat Who Talked America into the Great War. North Melbourne: Arcadia, 2016.

Documents Relative to the Sinn Fein Movement. CMD 1108. London: HMSO, 1921.

Doerries, Reinhard R. Imperial Challenge: Ambassador Count Bernstorff and German-American Relations, 1908-1917. Christa D. Shannon (Trans.). Chapel Hill: University of North Carolina Press, 1989.

Doerries, Reinhard R. Prelude to the Easter Rising: Sir Roger Casement in Imperial Germany. London: Frank Cass, 2000.

Dudgeon, Jeffrey. Roger Casement: The Black Diaries with a Study of his Background, Sexuality, and Irish Political Life. Belfast: Belfast Press, 2002.

Edwards, O. Dudley and Fergus Pyle (Eds.). 1916: The Easter Rising. London: Macgibbon and Kee, 1968. 
Freeman, Peter. "MI1(b) and the Origins of British Diplomatic Cryptanalysis." Intelligence and National Security 22, no. 2 (2007): 206-228.

Freeman, Peter. "The Zimmermann Telegram Revisited: A Reconciliation of the Primary Sources". Cryptologia 30, no. 2 (2006): 98-150.

Gannon, Paul. Inside Room 40: The Codebreakers of World War 1. Hersham: Ian Allan, 2010.

Gathen, Joachim von zur. "Zimmermann Telegram: The Original Draft”. Cryptologia, 31/1 (2007), 2-37.

Grant, Robert M. U-Boat Intelligence 1914-1918. London : Putnam, 1969.

Grob-Fitzgibbon, Benjamin. Turning Points of the Irish Revolution: The British Government, Intelligence, and the Cost of Indifference, 1912-1921. Basingstoke: Palgrave Macmillan, 2007.

Headrick, Daniel R. The Invisible Weapon: Telecommunications and International Politics, 1851-1945. Oxford: Oxford University Press, 1991.

Headrick, Daniel R. and Pascal Griset. "Submarine Telegraph Cables: Business and Politics, 1838-1939”. Business History Review 75 (2001): 543-578.

Hezlet, Arthur. The Electron and Sea Power. London: Cox \& Wyman, 1975.

Hines, Jason. "Sins of Omission and Commission: A Reassessment of the Role of Intelligence in the Battle of Jutland". Journal of Military History 72, no. 4 (2008): 1117-1154.

Inglis, Brian. Roger Casment. London: Hodder and Stoughton, 1973.

James, William. The Eyes of the Navy: A Biographical Study of Admiral Sir Reginald Hall K.C.M.G., C.B., LL.D., D.C.L. London: Methuen, 1955.

Jeffery, Keith. 1916: A Global History. London: Bloomsbury, 2015.

Kautt, The Anglo-Irish War, 1916-1921: A People's War. London: Praeger, 1999.

Kennedy, Christopher. Genesis of the Rising 1912-1916: A Transformation of Nationalist Opinion. New York: Peter Lang, 2010.

Larsen, Daniel. "British Codebreaking and American Diplomatic Telegrams, 1914-1915." Intelligence and National Security 32, no. 2 (2017): 256-263.

Larsen, Daniel. "British Intelligence and the 1916 Mediation Mission of Colonel Edward M. House." Intelligence and National Security 25, no. 5 (2010): 682-704.

Larsen, Daniel. "Intelligence in the First World War: The State of the Field." Intelligence and National Security 29, no. 2 (2014): 282-302.

Larsen, Daniel. "War Pessimism in Britain and an American Peace in Early 1916". International History Review 34, no. 4 (2012): 795-817. 
McGarry, Fearghal. The Rising: Easter 1916. Oxford: Oxford University Press, 2010.

McHugh, Roger. "Casement and German Help" in Leaders and Men of the Easter Rising: Dublin 1916, F. X. Martin (Ed.). London: Methuen, 1967.

McMahon, Paul. British Spies and Irish Rebels: British Intelligence and Ireland, 1916-1945. Woodbridge: Boydell Press, 2008.

McNally, Michael. Easter Rising 1916: Birth of the Irish Republic. Oxford: Osprey, 2007.

Minutes of Evidence and Appendix of Documents, Royal Commission on the Rebellion in Ireland. London: HMSO, 1916.

Nickles, David Paull. Under the Wire: How the Telegraph Changed Diplomacy. Cambridge: Harvard University Press, 2003.

Northcott, Chris. MI5 at War 1909-1918: How MI5 Foiled the Spies of the Kaiser in the First World War, Philadelphia: Casemate, 2015.

Nowlan, Kevin B. (Ed.). The Making of 1916: Studies in the History of the Rising. Dublin: Stationery Office, 1969.

O’Halpin, Eunan. "British Intelligence in Ireland, 1914-1921" in The Missing Dimension: Governments and Intelligence Communities in the Twentieth Century, Christopher Andrew and David Dilks (Eds.). Urbana, Chicago: University of Illinois Press, 1984, 54-77.

Ó Broin, Leon. Dublin Castle and the 1916 Rising. London: Sidgwick \& Jackson,1966.

Official German Documents Relating to the World War. New York: Oxford University Press, 1923.

Porter, Bernard. Plots and Paranoia: A History of Political Espionage in Britain 1790-1988. London: Unwin Hyman, 1989.

Santoni, Alberto. "The First Ultra Secret: The British Cryptanalysis in the Naval Operations of the First World War.”Revue Internationale d'Histoire Militaire 63 (1985): 99-110.

Sawyer, Roger. Roger Casement's Diaries: 1910: the Black and the White. London: Pimlico, 1997.

Sloan, Geoff. "The British State and the Irish Rebellion of 1916: An Intelligence Failure or a Failure of Response?” Intelligence and National Security 28, no. 4 (2013): 453-494.

Walton, Calder. Empire of Secrets: British Intelligence, the Cold War and the Twilight of Empire. London: HarperPress, 2013.

Winkler, Jonathan Reed. "Information Warfare in World War I". Journal of Military History 73, no. 3 (2009): 845-867.

Winkler, Jonathan. Nexus: Strategic Communications and American Security in World War I. Cambridge: Harvard University Press, 2008. 